\title{
Effect of bunch covering on yield and fruit quality of "Barhee" date palm cultivar
}

\author{
Harhash $^{1}$ M.M., W.F.A. Mosa ${ }^{1}$, Safaa M. El-Nawam ${ }^{2}$ and Hassan R. H. Gattas ${ }^{2}$
}

${ }^{I}$ Plant Production Department, Faculty of Agriculture, Saba Basha, Alexandria University, Egypt. ${ }^{2}$ Horticulture Research Institute, Agriculture Research Center (ARC), Giza, Egypt. Received: 30 Nov. 2019 / Accepted 02 Jan. 2020 / Publication date: 15 Jan. 2020

\begin{abstract}
This study was conducted during two successive seasons 2018 and 2019 on twelve years old date palm trees (Phoenix dactylifera L.) cv. Barhee. The trees of were grown on sandy soil conditions under dripp irrigation system in a private orchard located at Wadi El-Natroun region, El-Behera governorate, Egypt. Eight bunches on each palm were selected uniformly and nearly in size and were subjected to five bunch covering treatments: control" without covering", white paper, kraft paper, white cloth and brown cloth at the beginning of fruit color break stages: end of kimri and beginning of bisir stages. The applied treatments were arranged in a randomized complete block design (RCBD) with three replicates (three trees) for each treatment. The obtained results showed that bunch weight in $\mathrm{kg}$ and yield in $\mathrm{kg}$ per palm were greatly increased by covering bunches with white paper and white and brown cloth as compared to control in both seasons. Moreover, they were also significantly increased by using kraft paper in the second season over control. Fruit weight was increased remarkably by using white or kraft paper and white or brown cloth in covering bunches of "Barhee" date palm over control in both experimental seasons. TSS percentage was greatly increased in the fruits which were produced from bunch covering with white or kraft paper and white or brown cloth over control. Moreover, white or brown cloth were superior in this term as compared to white or kraft paper in the two seasons.
\end{abstract}

Keywords: Date palm, Bunch covering, Yield, Fruit quality

\section{Introduction}

Date palm (Phoenix dactylifera L.) belongs to the family Arecaceae (syn. Palmaceae). It is one of the oldest cultivated fruit crops in the world and is believed to have originated around $6000 \mathrm{BC}$ (Johnson et al., 2013) from current Iraq which comprises 2600 species of palm trees, most of them living in tropical, subtropical and warm temperate climates. It is considered one of the leading most important fruits crop in Egypt, where is considers the highest country for date production over the world with 1.590 .414 million ton, around $18 \%$ of the global date production. Its fruiting area reached 49000.74 ha in 2018, (FAO, 2019).

Bagging spathes of date palm cultivars during flowering and fruit setting periods showed a beneficial effect on fruit set and yield, as well as accelerated ripening and improved fruit quality. Such treatment exhibited the highest fruit weight, flesh weight, total soluble solids, total sugars percentage and lowest tannins percentage (El-Salhy, 2000; Rabah and Kassam, 2003 and Moustafa, 2007). Moreover, they added that date palm bunch covers offer several advantages to protect fruits from high humidity and rain, from bird attacks and also from damage caused by insects and diseases.

There are three harvesting stages in which date palm should be harvested and could be merchandised; bisir or khalal, rutab and tamer and this can be defined basing on the advantages of the cultivar particularly soluble tannins standard, climatological conditions and the desire of the consumers (Awad, 2007). Gao et al. (2007) reported that date palm bunch covering offer several advantages in order to protect fruits from high humidity, rain, bird attacks and also from damage caused by insects. Furthermore, performing the coverage for the bunches from Khala stage by using mat baskets was more effective than plastic bags, hemp bags and cloth net bags against bunch wilt disorder (Shirazi et al., 2008). Harhash and Al-Obeed (2010) the same authors reported that bunch bagging with different materials and colors after 4 weeks from pollination until the bisir stage increased fruit and bunch weight and improved quality of both 'Succary' and 'Khalas' dates. Canvas, gauze or palm fibers, as well as polyethylene bagging with removing at later growth stages, caused a

Corresponding Author: W.F.A. Mosa, Plant Production Department, Faculty of Agriculture, Saba Basha, Alexandria University, Egypt. E-mail: walidbreeder@yahoo.com 
significantly early fruit ripening and improved the yield and fruit quality and also decreased the percentage of tip cracked fruits at harvest time comparing with unbagged (Harhash and Al-Obeed, 2010 and Kassem et al., 2011). Date palm cv. Barhee is marketed and consumed fresh at the mature full yellow (bisir) stage as a crispy apple-like fruit due to low contents of soluble tannins in contrast to many other cultivars (Al-Qurashi and Awad, 2011). The current study was conducted to investigate the influence of different bunch covering on yield and fruit quality of 'Barhee' dates.

\section{Materials and Methods}

The present study was carried out during two successive seasons 2018 and 2019 on twelve years old date palm trees (Phoenix dactylifera L.) cv. Barhee. Date palm trees were grown on sandy soil conditions in a private orchard located at Wadi El-Natroun region, El-Behera governorate, Egypt. The trees were spaced at $7 \times 6$ meters apart and irrigated by drip irrigation system and received the same cultural practices applied in the orchard. Moreover, date palm trees were uniform and healthy as possible in vigour and size. Eight bunches on each palm were selected uniformly and nearly in vigour and size and were subjected to five bunch covering treatments at the beginning of fruit color break stages: end of kimri and beginning of bisir stages. The applied treatments were arranged in a randomized complete block design (RCBD) with three replicates (three trees) for each treatment which were organized as follow:

1. Control" without covering "

2. White Paper.

3. Kraft Paper.

4. White cloth.

5. Brown cloth

\section{Measurements}

\section{Palm yield:}

The yield of palm tree was measured at the harvesting time by calculating the number and weight in $\mathrm{kg}$ of bunches per each palm.

\section{Fruit quality:}

At the time of the fruit ripening (fruit reached full maturity and 100\% yellow coloring), a sample of 50 fruit (50 replicate) was randomly collected from each treatment in order to estimate fruit physical and chemical characteristics.

\section{Fruit physical characteristics}

- Average fruit weight $(\mathrm{kg})$ by calculating the average of 50 fruits weight.

- Flesh weight $(\mathrm{g})$, seed weight $(\mathrm{g})$ and fruit size $\left(\mathrm{cm}^{3}\right)$ were measured and flesh /fruit ratio was calculated.

- Fruit length and fruit width $(\mathrm{cm})$ were measured with a caliper and fruit shape index (length/width) was estimated.

\section{Fruit chemical characteristics}

- Total soluble solids percentage in fruit juice (TSS) was determined using hand refractometer.

- Fruit acidity (\%) expressed as malic acid was determined in fruit juice by titrating with $0.1 \mathrm{~N}$ sodium hydroxide in the presence of phenolphthalein as an indicator according to A.O.A.C. (2000).

-TSS/acidity ratio was calculated.

- Fruit total sugars \%: were determined by using phenol sulfuric acid method according to Malik and Singh (1980).

- Fruit reducing sugars content was determined colorimetrically according to Nelson (1944).

- Non-reducing sugars were calculated by the difference between total sugars and reducing sugars.

- Soluble tannins content as a percentage from the fresh weight of date pulp was determined according to the method described by Swain and Hillis (1959). 
- Carotenoids and total chlorophyll contents (mg/100 g peel fresh weight) were achieved by the method of Moran and Porath (1980), as $80 \%$ acetone extract was chromatically assayed at $650 \mathrm{~nm}$, for total chlorophyll and $440 \mathrm{~nm}$ for carotene using Spectrophotometer.

\section{Statistical analysis:}

The obtained data were statistically analyzed by using one way analysis of variance (ANOVA). Least significant difference (LSD) at 0.05 level of probability was used to compare between the means of according to Steel and Torrie (1980). The statistical analysis was performed using SAS (Statistical Analysis System) version 9.13, (2008) was used to performing the statistical analysis for the obtained data.

\section{Results}

Data in Table 1 cleared that bunch weight in $\mathrm{kg}$ and yield in $\mathrm{kg}$ per palm were greatly increased by covering bunches with white paper and white and brown cloth as compared to control in both seasons. Moreover, they were also significantly increased by using kraft paper in the second season over control. Fruit weight was increased remarkably by using white or kraft paper and white or brown cloth in covering bunches of "Barhee" date palm over control in both experimental seasons.

Table 1: Effect of bunch covering application on bunch weight, yield and fruit weight of "Barhee" date palm during 2018 and 2019 seasons.

\begin{tabular}{lcccccc}
\hline \multirow{2}{*}{ Treatments } & \multicolumn{2}{c}{ Bunch weight $\mathbf{( K g )}$} & \multicolumn{2}{c}{ Yield (Kg) /palm } & \multicolumn{2}{c}{ Fruit weight (g) } \\
& $\mathbf{2 0 1 8}$ & $\mathbf{2 0 1 9}$ & $\mathbf{2 0 1 8}$ & $\mathbf{2 0 1 9}$ & $\mathbf{2 0 1 8}$ & $\mathbf{2 0 1 9}$ \\
\hline Without covering & 14.00 & 13.63 & 112.00 & 109.07 & 14.41 & 14.32 \\
White Paper & 17.67 & 16.80 & 141.33 & 134.40 & 16.09 & 16.52 \\
Kraft Paper & 15.25 & 15.50 & 122.00 & 124.00 & 15.86 & 15.58 \\
White cloth & 16.00 & 15.63 & 128.00 & 125.07 & 17.33 & 16.63 \\
Brown cloth & 16.00 & 16.23 & 128.00 & 129.87 & 15.48 & 16.06 \\
LSD $_{\mathbf{0 . 0 5}}$ & 1.45 & 0.80 & 11.59 & 6.43 & 0.68 & 1.07 \\
\hline
\end{tabular}

Results listed in Table 2 showed that Flesh weight was markedly increased by coverage Barhee date palm by white or kraft paper and by white or brown cloth as compared to control in 2018 and 2019 seasons.

Concerning to the influence of the different applied covering bags on seed weight, it was noticed that it was increased with control treatment but the differences were so slight not enough to be significant in the second season as compared to the other treatments. On the other side, the seed weight in the first year was significantly increased with control treatment which greatly differed from white paper and brown cloth.

Fruit size was markedly improved by using white or kraft paper and white or brown cloth in the two seasons.

Fruit length was increased obviously by bunch covering with white cloth and kraft paper comparing with control in the two seasons. Moreover, in the second season also it was also enhanced greatly by using white paper and brown cloth as compared to control.

Table 2: Effect of bunch covering on fruit physical characteristics of "Barhee" date palm during 2018 and 2019 seasons.

\begin{tabular}{|c|c|c|c|c|c|c|c|c|c|c|c|c|}
\hline \multirow[t]{2}{*}{ Treatments } & \multicolumn{2}{|c|}{$\begin{array}{c}\text { Flesh weight } \\
\text { (g) }\end{array}$} & \multicolumn{2}{|c|}{$\begin{array}{c}\text { Seed weight } \\
\text { (g) }\end{array}$} & \multicolumn{2}{|c|}{$\begin{array}{l}\text { Fruit size } \\
\qquad\left(\mathrm{cm}^{3}\right)\end{array}$} & \multicolumn{2}{|c|}{$\begin{array}{l}\text { Fruit length } \\
\qquad(\mathrm{cm})\end{array}$} & \multicolumn{2}{|c|}{$\begin{array}{c}\text { Fruit } \\
\text { diameter } \\
\text { (cm) }\end{array}$} & \multicolumn{2}{|c|}{ Fruit shape } \\
\hline & 2018 & 2019 & 2018 & 2019 & 2018 & 2019 & 2018 & 2019 & 2018 & 2019 & 2018 & 2019 \\
\hline Without covering & 12.99 & 12.96 & 1.42 & 1.36 & 13.44 & 13.28 & 3.14 & 3.25 & 2.51 & 2.38 & 1.26 & 1.37 \\
\hline White Paper & 14.80 & 15.16 & 1.29 & 1.36 & 15.81 & 16.17 & 3.40 & 3.41 & 2.40 & 2.40 & 1.42 & 1.42 \\
\hline Kraft Paper & 14.52 & 14.23 & 1.34 & 1.35 & 15.85 & 15.04 & 3.47 & 3.42 & 2.39 & 2.42 & 1.45 & 1.41 \\
\hline White cloth & 15.96 & 15.30 & 1.37 & 1.33 & 16.70 & 15.85 & 3.48 & 3.45 & 2.53 & 2.49 & 1.38 & 1.39 \\
\hline Brown cloth & 14.24 & 14.73 & 1.23 & 1.33 & 15.44 & 15.80 & 3.32 & 3.36 & 2.36 & 2.38 & 1.41 & 1.41 \\
\hline $\mathbf{L S D}_{0.05}$ & 0.69 & 1.05 & 0.13 & 0.12 & 0.75 & 1.05 & 0.27 & 0.07 & 0.09 & 0.03 & 0.13 & 0.03 \\
\hline
\end{tabular}


Fruit diameter was increased with white cloth and control treatment in the first season. On the other hand, it was increased remarkably with white cloth, kraft paper over control in the second season.

Fruit shape was statistically increased by covering bunches of date palm cv. Barhee with white paper, kraft paper and brown cloth with comparing to control in both experimental seasons.

Results in Table 3 cleared that TSS percentage was greatly increased in the fruits which were produced from bunch covering with white or kraft paper and white or brown cloth over control. Moreover, white or brown cloth were superior in this term as compared to white or kraft paper in the two seasons.

The fruit content from acidity was increased significantly by covering bunches of "Barhee" date palm with brown cloth over control in the first season. Moreover, there are no significant differences detected between the use of white paper, kraft paper, white cloth and control treatment in the two seasons.

TSS/ acidity ratio was obviously increased by using white paper and kraft paper comparing with control in the two seasons. Furthermore, it was also enhanced by using white cloth over control in the second seasons. On the opposite side, it was greatly decreased when brown cloth was used in covering "Barhee" date palm as compared to control in both seasons.

Total sugars were markedly increased by using white or kraft paper and white or brown cloth over control in both experimental seasons.

Concerning to reducing sugars, they were enhanced by covering bunches of "barhee" date palm with kraft paper and white cloth more than control during 2018 and 2019 seasons. Moreover, they were also raised by using brown cloth on bunches comparing with control in the first season. Besides, in the second season they were improved by using white paper over control.

Non reducing sugars were significantly increased by using kraft paper and white cloth as compared to control in the second season. On the opposite side, in the first season they were enhanced by covering "Barhee" date palm by white or kraft paper and white or brown cloth but the differences were so slight not enough to be significant as compared to control.

Table 3: Effect of bunch covering on fruit chemical characteristics of "Barhee" date palm during 2018 and 2019 seasons.

\begin{tabular}{|c|c|c|c|c|c|c|c|c|c|c|c|c|}
\hline \multirow[t]{2}{*}{ Treatments } & \multicolumn{2}{|c|}{ TSS \% } & \multicolumn{2}{|c|}{ acidity $\%$} & \multicolumn{2}{|c|}{ TSS/ acidity } & \multicolumn{2}{|c|}{$\begin{array}{c}\text { Total sugars } \\
\text { (\%) }\end{array}$} & \multicolumn{2}{|c|}{$\begin{array}{c}\text { Reducing } \\
\text { sugars } \\
\text { (\%) }\end{array}$} & \multicolumn{2}{|c|}{$\begin{array}{c}\text { Non } \\
\text { reducing } \\
\text { sugars }(\%)\end{array}$} \\
\hline & 2018 & 2019 & 2018 & 2019 & 2018 & 2019 & 2018 & 2019 & 2018 & 2019 & 2018 & 2019 \\
\hline Without covering & 26.00 & 26.20 & 0.22 & 0.26 & 177.74 & 100.77 & 21.53 & 21.62 & 14.86 & 14.29 & 6.67 & 7.33 \\
\hline White Paper & 30.70 & 30.30 & 0.19 & 0.21 & 162.49 & 146.63 & 26.00 & 26.06 & 16.91 & 17.94 & 9.09 & 8.12 \\
\hline Kraft Paper & 33.90 & 32.50 & 0.23 & 0.23 & 148.02 & 141.44 & 30.80 & 29.87 & 18.95 & 18.22 & 11.85 & 11.65 \\
\hline White cloth & 35.80 & 32.90 & 0.26 & 0.25 & 139.67 & 130.36 & 30.71 & 29.12 & 20.77 & 18.63 & 9.93 & 10.49 \\
\hline Brown cloth & 36.10 & 34.40 & 0.31 & 0.30 & 124.67 & 117.50 & 29.00 & 25.57 & 20.16 & 16.29 & 8.84 & 9.48 \\
\hline LSD $_{0.05}$ & 1.4 & 2.5 & 0.06 & 0.04 & 28.38 & 24.45 & 5.02 & 3.19 & 2.89 & 3.16 & 5.66 & 3.13 \\
\hline
\end{tabular}

According to the data listed in Table 4, it was noticed that control treatment increased significantly carotene content in the fruits as compared to the other covering treatments with the exception of the covering with white cloth in the first season where the differences were not significant.

Total chlorophyll was significantly increased by the use of white paper in bunch covering as compared to control in both experimental seasons. Moreover, it was also enhanced obviously by the use of white cloth in the second season over control. On the opposite side, it was statistically decreased by using kraft paper and brown cloth in bunch coverage comparing with control in the two seasons.

Total tannins percentage was greatly raised by using kraft paper and brown cloth in bunch covering over control in the two seasons. Furthermore, bunch covering with white paper and white cloth also significantly raised the fruit content from total tannins over control in both seasons. 
Table 4: Effect of bunch covering on fruit carotene content, total chlorophyll and total tannins percentage of "Barhee" date palm during 2018 and 2019 seasons.

\begin{tabular}{lcccccc}
\hline \multirow{2}{*}{ Treatments } & \multicolumn{2}{c}{ Carotene $\mathbf{~ m g / 1 0 0 g}$} & \multicolumn{2}{c}{$\begin{array}{c}\text { Total chlorophyll } \\
\mathbf{m g} / \mathbf{1 0 0 g}\end{array}$} & \multicolumn{2}{c}{ Total tannins (\%) } \\
\cline { 2 - 7 } & $\mathbf{2 0 1 8}$ & $\mathbf{2 0 1 9}$ & $\mathbf{2 0 1 8}$ & $\mathbf{2 0 1 9}$ & $\mathbf{2 0 1 8}$ & $\mathbf{2 0 1 9}$ \\
\hline Without covering & 4.81 & 6.42 & 1.35 & 1.40 & 0.29 & 0.25 \\
White Paper & 1.97 & 2.54 & 1.92 & 2.35 & 0.66 & 0.72 \\
Kraft Paper & 1.07 & 1.40 & 0.48 & 0.51 & 1.10 & 0.95 \\
White cloth & 3.48 & 2.39 & 1.39 & 2.27 & 0.74 & 0.86 \\
Brown cloth & 0.91 & 1.11 & 0.39 & 0.25 & 0.91 & 0.86 \\
LSD 0.05 & 1.74 & 1.09 & 0.52 & 0.24 & 0.18 & 0.14 \\
\hline
\end{tabular}

\section{Discussion}

Our obtained data are in agreement with the findings of (Galib et al., 1988), they found that bunch bagging with paper bags during 4 weeks from pollination increased fruit set and yield of 'Hallawy' date cultivar. Furthermore, the obtained results were previously explained by Chillet and Jamnoyer (1996). They reported that bagging raised the temperature around bunches and reduced the shooting until harvesting time under temperate conditions and microclimate surrounding the bunch could favourably be changed by bunch covering. Moreover, bunch bagging of 'Rothana' date palm cultivar with grill cloth increased remarkably fruit weight, flesh weight, fruit volume, SSC, total and reducing sugars followed by bagging with kraft paper (El-Salhy, 2000; Awad, 2007 and Harash and Al-Obeed, 2010). Additionally, Rabeh and Kassem (2003) reported that bagging spathes of "Zaghloul" and "Samani" date palm cultivars during flowering and fruit setting periods showed a beneficial effect on fruit set, yield and physical and chemical properties. Besides, Awad (2007) reported that bunch bagging with different materials and colors after 1 month from pollination until harvest accelerated the ripening rate of 'Helali' dates. Moreover, the same author found that bagging with grill cloth and kraft paper improved significantly SSC, total and reducing sugars. Bagging spathes of date palm exhibited the highest total soluble solids, total sugars percentage and lowest tannins percentage (Moustafa, 2007). Al-Obeed and Harhash (2010) noticed that bagging treatments significantly increased the fruit total soluble solids and reduced and non-reduced sugars compared to not bagging. Moreover, in the same trend Harhash and Al-Obeed (2010) stated that bunch bagging with different materials and colors after 4 weeks from pollination until the bisir stage increased fruit and bunch weight of both 'Succary' and 'Khalas' dates. Moreover, they added that bunches bagging exhibited the highest total soluble solid percentage and lowest tannin percentage of date palm.

The obtained results are in agreement with the findings of Mostafa, et al. (2014), they indicate that TSS \% and sugar contents were significantly varied according to bagging treatments. Furthermore, bagging with white, blue or black perforated polyethylene bags significantly increased TSS \% and sugar contents comparing with control. Whereas, using either green perforated polyethylene bag, sackcloth or gauze bags significantly decreased TSS $\%$ and total sugars contents compared to control. Additionally, using bagging with black color bags gave the highest TSS \% whereas, using blue color bags gave the highest total sugars content in comparison to other bagging treatments. On the opposite side, it was noticed that the usage of gauze bags decreased T.S.S. \% and total sugars comparing with the other treatments. In addition, the obtained results are in the same trend with the findings of Omar et al. (2014), where they performed a study during 2011 and 2012 seasons and used different materials of bagging and investigated their effect on fruit set, yield and fruit quality of 11 years old date palm cv. Rothana. They used paper kraft and grill cloth after pollination for one month, as compared to control (unbagged). The obtained results showed that all the covering treatments improved fruit set, bunch weight, fresh fruit weight, fruit flesh weight, total and reducing sugars contents comparing with control. Besides, physical and chemical characteristics were greatly improved by using grill cloth over the other applied covering treatments. 


\section{References}

A.O.A.C., 2000. Official Methods of Analysis. Association of Official Analytical Chemists, Inc. Vitamins and other nutrients. (17 $7^{\text {th }}$ ed.), Washington, D.C. 16-20.

Al-Obeed, R.S. and M. M. Harhash, 2010. Effect of bunch bagging color on 'Succary' and 'Khalas' date palm cultivars: fruit chemical characteristics. Acta Hort. 882: 1213-1218.

Al-Qurashi, A.D. and M.A. Awad, 2011. Naphthalene acetic acid increase bunch weight and improve fruit quality of 'Barhee' date palm cultivar under hot arid climate. Amer. Eurasian. J. Agr. Environ. Sci., 10(4): 569-573.

Awad, M.A., 2007. Increasing the rate of ripening of date palm fruit (Phoenix dactylifera L.) cv. Helali by preharvest and postharvest treatments. Postharvest Biol. Technol., 43(1):121-127.

Chillet, M. and M. Jamnoyer, 1996. Choice of bagging for the optimisation of banana growth condition. Infomusa 5(1): 25-27.

El-Salhy, A.M., 2000. Effect of bagging the spathes on "Zaghloul" date productivity under Assiut conditions. J. Agric. Sci., 31(3):123-134.

FAO., 2019. FAOSTAT. Food and Agriculture Organization of the United Nations, Rome, Italy. http://faostat.foa.org.

Galib, H.A., E.A. Mawlood and H.H. Hamood, 1988. The Influence of bagging on fruit set and fruit characteristics in date palm cv. Hallawi. Date Palm J. 6, 238-254.

Gao, W.S., D.G. Lv, C. Yu, S.J. Qin, G.D. Du and D.Y. Zhao, 2007. Study on microorganism population structure in microenvironment of bagged apple fruit. J. Fruit Sci., 24(6): 830-832.

Harhash, M.M. and R.S. Al-Obeed, 2010. Effect of bunch bagging color on yield and fruit quality of date palm. American Eurasian J. Agric. Environ. Sci., 7(3): 312-319.

Johnson, D.V., J.M. Al-Khayri and S.M. Jain, 2013. Seedling date palms (Phoenix dactylifera L.) as genetic resources. Emir. J. Food Agric., 25(11):809-830.

Kassem, H.A., A.K.H. Omar and M.A. Ahmed, 2011. Response of Zaghloul palm productivity, ripening and quality to different polyethylene bagging treatment. American Eurasian J. Agric. Environ. Sci., 11(5): 616-621.

Malik, C.P. and M.B. Singh, 1980. Extraction and estimation of amino acids and keto acids. In: Plant enzymology and histoenzymology. (Eds.): CP. Malik, MB. Singh, Kalyani Publishers, New Delhi-Lud Hana, India, 286.

Moran, R. and D. Porath, 1980. Carotenoids determination in intact tissues. Plant Physiol., 65:478479.

Mostafa, R.A.A., A.M. El-Salhy, A.A. El-Banna and Y.M. Diab, 2014. Effect of Bunch Bagging on Yield and Fruit Quality of Seewy Date Palm under New Valley Conditions (Egypt). Middle East j. Agric. Res., 3(3): 517-521.

Moustafa, A.A., 2007. Effect of bagging period of spathes after pollination on fruit set, yield and fruit quality of "Sewey" dates under Fayoum governorate conditions. Proceeding of the Fourth Symposium on the Date Palm in Saudi Arabia, Al- Hassa. P: 123.

Nelson, N., 1944. Determination of reduced sugars. J. Biol. Chem., 153:375.

Omar, A. K., A.M. Al-Saif and M.A. Ahmed, 2014. Bagging of bunches with different materials influences yield and quality of Rothana date palm fruit. J. Food, Agric. Environ., 12 (2): 520 522.

Rabeh, M.R.M. and H.A. Kassem, 2003. The effect of bagging the spathes after pollination on yield and quality of "Zaghloul" and "Samany" dates. Zagazig J. Agric. Res. 21(3B): 935-944.

SAS Institute Inc. 2008. SAS Institute Inc., SAS Users Guide. SAS/STAT, Version 6.12, SAS Institute Inc., Cary, NC.

Shirazi, M.P., M. Izadi and R. Khademi, 2008. Study the climatical factors effects on bunch fading disorder of date palm in southern Iran and the methods of its control. American-Eurasian $\mathrm{J}$. Agric. Environ. Sci., 4: 570-574.

Steel, R. and J. Torrie, 1980. Principles and Procedures of Statistics: A Biometrical Approach. 2nd Edition, Mc Graw-Hill Book Company. New York, U.S.A. p. 580.

Swain, T. and W.E. Hillis, 1959. The phenolic constituents of plum (Prunus domestica). 1- The quantitative analysis of phenolic constituents. J. Sci. Food Agri., 10: 63-68. 